\title{
The Effect of Corporate Governance on Foreign Direct Investment in Jordanian Commercial Banks Listed at Amman Stock Exchange
}

\author{
Dr. Mohammad Al-Dwiry \\ Dr. Waseem Al- Haddad \\ Al-Ahliyya Amman University \\ Postal Address: 19328 \\ Amman, Jordan \\ Dr. Zyad Marashdeh \\ The Hashemite University \\ Postal Code: 13115 \\ Zarqa, Jordan
}

\begin{abstract}
This study aimed to provide evidence of whether or not the corporate governance \& foreign direct investment indicators of the Jordanian commercial banks listed at Amman Stock Exchange (ASE) are affected by variables that were proposed and to provide the important indicators of the relationship of corporate governance that can be used by the Jordanian commercial banks to attract the foreign direct investment. The study population consists of 13 Jordanian commercial banks governance of the Jordanian banks listed at Amman Stock Exchange (ASE). The study founds that there is a direct positive relationship between profitability -measured either by Earnings per share (EPS) and Return on assets (ROA) - and corporate governance. In contrast, a negative direct relationship between each of liquidity, return on equity (ROE), and the size of the company with corporate governance, finally the study found a positive direct relationship between corporate governance and foreign direct investment.
\end{abstract}

Key Words: Corporate governance, direct foreign investment, Jordanian commercial banks

\section{Introduction}

Historically, the Jordanian economy has benefited from the massive investment by the Gulf countries, which has continued to skyrocket until 2006. However, since then FDI has declined due to the international economic crisis, followed by geopolitical instability, and have since remained stable. According to data from UNCTAD, FDI inflows totaled to USD 950 million in 2018, showing a decrease compared to the previous year (USD 2.0 billion). Estimated at USD 35 billion, the total stock of FDI represents 82.9\% of the country's GDP (UNCTAD's 2019 World Investment Report). In order to boost FDI flows, the government has planned large-scale infrastructure projects (water, transportation, nuclear energy) for which it needs foreign and private funds. A project linking the Dead Sea to the Red Sea was expected to start in 2018, but was postponed as Jordan could not reach an agreement with Israel on how to construct the canal. Nevertheless, the Israeli opposition seems to have dwindled and the Israeli government said early 2019 that it was ready to move ahead with the project.

Jordan is trying to become a regional logistics hub, notably for electric and transport networks. Investments are mainly concentrated in the field of real estate (residential and commercial), financial services and large tourism projects. The country's attractiveness lies mainly in the quality of its infrastructure, its solid and dynamic banking system, as well as its level of economic openness, which has allowed the establishment of free trade zones and public-private partnerships. Problems linked to bureaucracy, corruption and investment protection are obstacles to FDI.

In this paper we tested the effect of factors, (Earnings per share, Liquidity, Size, Return on assets, Return on equity, on corporate governance, and to examine the impact of corporate governance to attract Foreign Investments (FDI) To Amman Stock Exchange). In 2014, Jordan enacted an investment law, which strengthens in particular the Jordan Investment Commission, whose purpose is to support investors. However, some observers criticized the focus on tax exemptions, instead of trying to improve the overall business climate. In addition, the World Bank continues to assess negatively the national business climate in Jordan. Thus, the country had lost several places in the Ease of Doing Business ranking and ranked 104th out of 190 countries on the World Bank 2019 Doing Business report, losing one spot from a year earlier. 
Previous studies reached too many determinants of FDI such as, Inflation, Exchange Rate, and risk profile of host country, but few studies measure the impact of corporate governance on foreign investment at Amman Stock Exchange (ASE). Our research intends to prove the effect of corporate governance on foreign direct investment.

FDI is not only Multinational Enterprises (MNE), Its contributes as a key role to develop human resources, through transfer significant skills and technology which will lead to attract a lot of external experiences that can improve most of economic indicators of the host country, Further More it may also minimize the possibility of bad corporate governance transfer best practices from their home countries (Ajay, 2006).

The commonly accepted goal of an MNC is to maximize shareholder wealth. Man- agers employed by the MNC are expected to make decisions that will maximize the stock price and therefore serve the shareholders. Some publicly traded MNCs based outside the United States may have additional goals, such as satisfying their respective governments, banks, or employees. However, these MNCs now place more emphasis on satisfying shareholders so that they can more easily obtain funds from shareholders to support their operations. And to reach to this goal they should pursuing shareholders to invest in high corporate governance corporation's profiles (Madura, 2014).

The implantation of corporate governance with global best practices and standards has also become a vital part of high corporate performance, Thus Foreign investors are attracted to corporation with high corporate governance profile.

\section{Problem Statement}

The main idea of this research is to examine whether or not the factors Independent variables taken at this research can determine the percentage of FDI in Jordanian commercial banks listed at Amman stock exchange (ASE) through corporate governance. The research is trying to answer the following questions:

1. What are the factors which might affect the corporate governance of Jordanian commercial banks?

2. What is the effect of corporate governance on foreign direct investment (FDI)?

3. What are the factors that which might affect foreign direct investment (FDI)?

\section{Significant of the study}

The importance of this research based on the following points:

1. Provide evidence if the corporate governance and FDI of the Jordanian commercial banks listed at (ASE) are affected by (Independent Variables), that were proposed.

2. Provide vital indicators of THE relationship of corporate governance and FDI in Jordanian commercial banks listed at (ASE) to solve agency problem.

\section{Theoretical Background}

\section{Corporate Governance}

Corporate Governance is basically concerned with ways in which all parties interested in the well-being of the firm (the stakeholders) attempt to ensure that managers and other insiders are always taking appropriate measures or adopt mechanisms that safeguard the interests of the stakeholders. Such measures are necessitated because of the separation of ownership from management, an increasingly vital feature of the modern corporations.

A typical firm is characterized by numerous owners having no management role, and with managers with no equity interest in the firm. Shareholders, or owners' equity, are generally large in number, and an average shareholder controls a minute proportion of the shares of the firm. This gives rise to the tendency for such a shareholder to take no interest in the monitoring of managers, who, left to themselves, may pursue interests different from those of the owners of equity.

The compatibility of corporate governance practices with global standards has also become an important part of corporate success. The practice of good corporate governance has therefore become a necessary prerequisite for any corporation to be manage effectively in the globalize market. The term "corporate governance" is relatively new terminology used in both public and academic debates, although the issues it addresses have been around for much longer. In the last two decades, however, corporate governance issues have become important not only in the academic literature, but also in public policy debates. During this period, corporate governance has been identified with takeovers, financial restructuring, and institutional investors' activism Ross 1973), and Shleifer \& Vishny, (1997) define corporate governance by stating that it deals with the ways in which suppliers of finance to corporations assure themselves of getting a return on their investment.

On other hand, there is a positive relationship between company governance on foreign ownership of the banks. Within this context. It become recognized that there's a strong dating between operations of overseas banks and governance degrees of the countries. In This regard, it become determined that the factors of corruption, political 
stability, rule of regulation and versatility in prison regulations affect overseas financial institution operations. (Tunay \& Yüksel , 2017)

\section{Literature Review}

Ezekiel (2018) conducted a study entitled: "Corporate governance practices and foreign direct investment: the case of Nigerian listed companies". This paper examines the relationship between corporate governance practices and foreign direct investment using a sample of 186 listed companies in Nigeria over the periods that range from 20082010 and 2012-2014. The two periods represent the pre and post-corporate governance review periods in Nigeria. Corporate governance quality was measured using the corporate governance index from the publicly disclosed information in financial statements. Foreign direct investment data was measured by the percentage of the share holds by the foreign investors (institutions and individuals) to the total quoted share for each of the listed company in Nigeria. The findings of this study showed that corporate governance has a significant impact on the inflow of foreign direct investment into the Nigeria stock market. Thus, listed companies in Nigeria have to enhance their corporate governance practices in order to attract more funds from foreign investors.

Praveen Das (2014) conducted a study entitled: "The role of corporate governance in foreign investment". This paper investigates whether and how the corporate governance practices of companies affect foreign investors' decisions to invest in their companies. Based on a comprehensive data set of foreign equity holdings of mutual funds from 37 countries, the paper shows that fund managers tend to tilt their portfolio weights towards companies with strong governance systems. In particular, they invest more in foreign companies with good board characteristics and independent auditors. This result suggests that mutual funds, facing informational disadvantage in their foreign investments, prefer companies with better governance systems as a substitute for their own costly information acquisition and monitoring activities. Moreover, irrespective of their country-level investor protection environments, companies with better governance structures attract more foreign investments.

Alsubaie (2012) conducted a study entitled: "The influence of foreign direct investment on corporate-governance practices: a conceptual framework". This study aims to determine the scope of foreign direct investment effects beyond those that have a direct impact on acquired local companies. More specifically, it aims to clarify the role played by FDI on corporate governance changes, such as changes in board of directors, ownership concentration, executive compensation, and investor protection. The study shows the significant role that FDI plays in organizing both economic and social institutions. It also establishes a framework to investigate the nature of the relationship between FDIs and local companies on one hand, and their effect on the corporate governance of local companies on the other hand. The results of this study reveal positive effects of foreign direct investment (FDI) on economic growth, technology transfer and productivity of local companies. Furthermore, the study has shown positive effects of FDI in corporate-governance practices with regard to local companies that have either been entered into joint venture with or acquired by foreign companies.

Alba. et.al (2010) conducted a study entitled: "Corporate governance and foreign direct investment". According to this paper, Merger and acquisition (M\&A) is used to promote corporate governance, it suggests that improvements in corporate governance may have a negative impact on merger and acquisition. Since M\&A foreign direct investment (FDI) is a cross-border variant of M\&A, stronger corporate governance may also help to reduce M\&A FDI. Thus, this paper used firm-level evidence from Japanese FDI into the United States to examine the effect of US corporate governance on Japanese M\&A FDI. The results of this study show that the two landmark corporate governance regulations by the US Securities and Exchange Commission in 1992 have contributed significantly to the sharp decline in Japanese M\&A FDI in the US during the 1990s. This evidence provides some support to the notion that corporate governance may affect not only domestic M\&A activity but also cross-border M\&A activity. This study has also focused on the puzzle of why Japanese FDI into the US fell during the 1990s despite the depreciation of the US dollar.

\section{Research Methodology}

\section{Data Collection}

1. Banks must be listed at (ASE) throughout the period of the study (2009-2018).

2. Annual reports of a bank must be obtainable.

3. Company guide published by (ASE) for research years.

4. Foreign direct investment (FDI) must be published by securities depositary center (SDC) and Jordan securities commission (JSC). 


\section{Research Variables}

The Research consists of independent variables (Earning per share, Liquidity, Return on Assets, Size, Return on Equity, largest shareholders and Dummy variable) also a mediator variable (Corporate Governance) and the dependent variable (Foreign Direct Investment).

\section{Independent Variables}

On this phase, the numerous firm unique attributes - suggested through agency theories and former research - and the proxies which can be used to capture such attributes may be indexed.

- Earnings per share (EPS) is calculated as a company's profit divided by the outstanding shares of its common stock. The resulting number serves as an indicator of a company's profitability. It is common for a company to report EPS that is adjusted for extraordinary items and potential share dilution. The higher a company's EPS, the more profitable it is considered, also good corporate governance practices.

- Liquidity: Liquidity ratio may have an important impact on firm's performance. Firms with greater liquid assets (in which it can cover all current liabilities through its current assets) may use these assets to finance their investments. That will enhance the performance of the firm. In line with preceding researches, they found that there is a positive relation between liquidity and ownership that will be used as a corporate governance proxy in this study.So, to measure the previous mentioned relationship, this study uses the ratio of Current Assets (CA) to Current Liabilities (CL), as a proxy for the liquidity of the firm's assets, using this formula:

Liquidity it $=$ Current Assets it $/$ Current Liabilities it

- Size: logarithm of total assets

- Return on assets (ROA): is an indicator of how profitable a company is relative to its total assets. ROA gives a manager, investor, or analyst an idea as to how efficient a company's management is at using its assets to generate earnings. Return on assets is displayed as a percentage and can be calculated for any company if net income and total assets are both positive numbers.

- Return on equity (ROE): is an indicator of how profitable a company is relative to its total equity. Return on equity (ROE) is a measure of financial performance calculated by dividing net income by shareholders' equity.

Return on equity is displayed as a percentage. It's considered a good indicator to Attract DFI. ROE is expressed as a percentage and can be calculated for any company if net income and equity are both positive numbers. Net income is calculated before dividends paid to common shareholders and after dividends to preferred shareholders and interest to lenders.

- Dummy variable: number of years

\section{Mediator Variable}

Corporate Governance: are defined as those having $1 \%$ percent or more of the bank capital equity and do not serve as an executive officer or director (Chen, et al. 2019; Kolsi \& Grassa, 2017; Mersni \& Ben Othman, 2016; Ching et al.,2006; Peasnell et al. ,2005; Shleifer and Vishny ,1997; Jensen ;1993).

It is calculated using the ownership of $1 \%$ or above from the total ownership (largest shareholders) for the period from 2009 till 2018, where the dependent variable in the first step (direct relationships) and the mediator variable in the second step (indirect relationships).

"Historically, institutional investors dissatisfied with management or stock performance are known to pursue the "exit" mechanism, i.e. selling the stock holdings. However the "exit" mechanism is becoming costlier as their portfolios became so big and dumping large holdings may cause steep declines available prices

A foreign institutional investor (FII) is any type of large investor who does business in a country other than the one in which the investment instrument is being purchased. In addition to the types of investors above, others include banks, large corporate buyers or representatives of large institutions. All FIIs take a position in a foreign financial market on behalf of the home country in which they are registered.

Corporate governance is crucial in attracting investors because they send the proper signal to both domestic and foreign investor in respect of the potential risk of their investment. Thus, FDI is positively related to improvement in corporate governance (CG). Adelopo, et al (2009).

\section{Dependent Variable}

Foreign Direct Investment (FDI): Stocks measure the total level of direct investment at a given point in time, usually the end of a year. 
The highest foreign ownership percentage that exceeds $1 \%$ was obtained for each Jordanians banks, from the ASE' and SDC websites.

\section{Hypothesis of the Study}

The following are the hypothesis of the study based on the questions of the study:

Ho There is no significant relationship between the independent variables and FDI (measured by foreign ownership percentage that exceeds 1\%) of the listed Jordanian banks, using corporate governance as a mediator variable.

\section{Sub-Hypothesis}

Hol There is no significant relationship between EPS and Foreign Direct Investment.

Ho2 There is no significant relationship between Liquidity and Foreign Direct Investment.

Ho3 There is no significant relationship between ROA and Foreign Direct Investment.

Ho4 There is no significant relationship between size (logTA) and Foreign Direct Investment.

Ho5 There is no significant relationship between ROE and Foreign Direct Investment.

Ho6 There is no significant relationship between Dummy variable and Foreign Direct Investment.

\section{Operational Definitions}

- Foreign Direct Investment: It is the improvement FDI ownership in banks.

- Corporate Governance: Average ownership of (1\%) or above of the total ownership during the year 20092018.

\section{Research Models}

In this section we will use regression analysis to determine the overall efficiency scores derived from the pooled sample consisted of (13) Jordanian commercial banks. Listed at Amman Stock Exchange (ASE). The study consists of seven independent variables (Earning per share, Liquidity, Return on Assets, Size, Return on Equity, largest shareholders and Dummy variable) also a mediator variable (Corporate Governance) and the dependent variable (Foreign Direct Investment). We used 2SLS mainly because we face the issue of simultaneity bias (when we have endogenous variables in system of equations). In such a case, the error terms are correlated with the independent variables. The method is called "two-stage" because it conducts estimation in two steps. Using the following equations:

$$
C G_{t}=\alpha 0+\beta 1 E P S_{t}+\beta 2 L I Q_{t}+\beta 3 \operatorname{LogTA}_{t}+\beta 4 R O A_{t}+\beta 5 R O E_{t}+\beta 6-15 \operatorname{YearDUM}_{+} \varepsilon_{t}
$$

Where:

CG: Corporate Governance

EPS: Earning Per Share

LIQ: Liquidity

ROE: Return on Equity

ROA: Return on Assets

LogTA: logarithm of Total Assets

$\beta$ : Coefficient

DUM: Dummy variable

$\varepsilon_{t}:$ Residual

The result of this equation (1) then will be compensated in the following equations:

$$
D F I=\beta_{0+} \beta_{1} N C G_{t+} \varepsilon_{t}
$$

Where:

NCG: Fitted value for corporate governance driven from equation (1)

$\beta$ : Coefficient

$\varepsilon_{t}:$ Residual

And before estimation of the equations, it is a must to make the following test to insure getting the efficient results:

The Unit Root Test: since variables are mostly non - stationary and because the OLS approach gives spurious results when data is a non-stationary which requires testing the variables whether they are stationary or not. The stationary test would be measured through testing the stability of mean and variance through a period of time, in 
addition, the value of covariance between any closed values depends only on the lag period. In this field, both of Dickey and Fuller (DF) improved a test for the above mentioned conditions. But because the data is pooled; we can't use the DF test. So we will use the Levin, Lin and Chu (LLC) test to test stationary. Choosing between fixed and random effects: the generally accepted way of choosing between fixed and random effects is running a Hausman test. Statistically, fixed effects are always a reasonable thing to do with panel data (they always give consistent results) but it may not be the most efficient model to run. Random effects will give you better P-values as they are a more efficient estimator, so you should run random effects if it is statistically justifiable to do so.

The Hausman test checks a more efficient model against a less efficient but consistent model to make sure that. The more efficient model also gives consistent results. To test the significant of the model the researcher will apply the following tests T-test, F-test, DW- Test.

\begin{tabular}{|l|l|}
\hline $\begin{array}{l}\text { Table } 1 \\
\text { Hausman Test Results }\end{array}$ \\
\hline chi2(14) & 3.05 \\
\hline Prob>chi2 & 0.9990 \\
\hline
\end{tabular}

After conducting the Hausman test, the random effect model appeared to be more appropriate for this study than the fixed effects model as the probability of this test exceeds $5 \%$.

\section{Table 2}

\section{Durbin- Watson}

\begin{tabular}{|l|l|}
\hline Model 1 & 2.041 \\
\hline Model 2 & 2.082 \\
\hline
\end{tabular}

As can be seen from the above table, Durbin and Watson d statistic test is equal or very close to 2 in the first and the second models thus no autocorrelation problem appear in these two models.

\section{Analysis, Results And Interpretations}

\section{Descriptive Statistics}

Table (2) presents the descriptive statistics for the main variables used in this study. The table shows that the mean (median) of EPS is 0.2101538 (0.29) respectively. In addition, the mean (median) of liquidity ratio is 0.4759437 (0.52). The bank size, as expressed by the natural logarithm of total assets, ranges from 8.47 to 10.41 . The average ROA is 1.214923 . The mean (median) of ROE is 8.20014 (10.78) respectively. Further, the average foreign ownership is $6 \%$, while the average for the largest shareholders ownership is $61 \%$.

\begin{tabular}{|l|l|l|l|l|l|}
\hline $\begin{array}{l}\text { Table 3 } \\
\text { Descriptive Statistics }\end{array}$ & Mean & Median & Std. Dev. & Min & Max \\
\hline Variables & 0.2101538 & 0.29 & 0.1461972 & -0.02 & 0.68 \\
\hline EPS & 0.4759437 & 0.5241973 & 0.0670803 & 0.314766 & 0.601949 \\
\hline LIQ & 9.326048 & 9.431787 & 0.4222469 & 8.477959 & 10.41262 \\
\hline LogTA & 1.214923 & 1.54 & .4829388 & -0.17 & 2.51 \\
\hline ROA & 8.20014 & 10.78 & 4.086575 & -1.45 & 16.87 \\
\hline ROE & 0.066332 & 0.092 & 0.0685525 & 0.00009 & 0.42864 \\
\hline FOREOW & 0.6118429 & 0.84664 & 0.2074975 & 0.16 & 0.89242 \\
\hline LARGST & &
\end{tabular}

Table 3 shows the Pearson correlations between the variables used in the multivariate analysis. The table reveals that the proxies for the hypotheses are not highly correlated with one another or with the control variables. The highest pair-wise correlation coefficient between the variables is 0.6227 , suggesting that multicollinearity is not a problem in our study.

\begin{tabular}{|c|c|c|c|c|c|c|c|}
\hline \multicolumn{8}{|c|}{$\begin{array}{l}\text { Table } 4 \\
\text { Correlation Matrix }\end{array}$} \\
\hline Variables & ROA & ROE & EPS & FSIZE & FOREOW & LARGST & LIQ \\
\hline ROA & 1.0000 & & & & & & \\
\hline ROE & $\mathbf{0 . 3 0 2 3} * * *$ & 1.0000 & & & & & \\
\hline EPS & $0.1756 * *$ & $0.5800 * * *$ & 1.0000 & & & & \\
\hline LogTA & 0.0653 & 0.1693* & $\mathbf{0 . 6 1 0 0}$ **** & 1.0000 & & & \\
\hline FOREOW & $0.3092 * * *$ & 0.1579 & 0.1832** & $0.2809 * * *$ & 1.0000 & & \\
\hline LARGST & -0.1098 & $-0.2350 * * *$ & -0.1116 & $-0.3687 * * * *$ & $-0.3709 * * *$ & 1.0000 & \\
\hline LIQ & 0.0225 & 0.0883 & 0.1590* & $0.2092 * *$ & $0.3183 * * *$ & $-0.2894 * * *$ & 1.0000 \\
\hline
\end{tabular}




\section{Multivariate Analysis}

Table (4) presents the results of multivariate pooled regression analysis for the first model used in this study. Overall, the study model is statistically significant, where $F$-value $=7.05$ and Prob $>F=0.000$. Further, the study model explains about $35 \%$ of the total variation of CG. As can be seen form table 4 , there is a significant positive relationship between EPS and CG (coefficient $=0.819$, and $\mathrm{p}<0.01$ ). However, a significant negative relationship has appeared between the liquidity and CG (coefficient $=-0.927$, and $\mathrm{p}<0.01$ ). Similarly, a significant negative relationship has appeared between the bank size and CG (coefficient $=-0.305$, and $\mathrm{p}<0.01$ ). Further, there is a significant positive relationship between ROA and CG (coefficient $=0.025$, and $\mathrm{p}<0.10$ ). In contrast, a significant negative relationship has appeared between the ROE and CG (coefficient $=-0.212$, and $\mathrm{p}<0.01$ ).

\begin{tabular}{|c|c|c|c|}
\hline \multicolumn{4}{|c|}{$\begin{array}{l}\text { Table } 5 \\
\text { Results of Multivariate Regression Analysis }\end{array}$} \\
\hline Variables & Coefficients & t. Statistic & p-value \\
\hline EPS & 0.8193704 & $2.72 * * *$ & 0.008 \\
\hline LIQ & -0.9275286 & $-3.07 * * *$ & 0.003 \\
\hline $\log T A$ & -0.3059749 & $-4.83 * * *$ & 0.000 \\
\hline ROA & 0.0257357 & $1.86^{*}$ & 0.053 \\
\hline ROE & -0.0212167 & $-4.52 * * *$ & 0.000 \\
\hline YearDUM & Inc. & Inc. & Inc. \\
\hline _Cons & 3.864391 & $6.19 * * *$ & 0.000 \\
\hline Adj R-squared & \multicolumn{3}{|l|}{$34.85 \%$} \\
\hline \multicolumn{4}{|c|}{$\begin{array}{l}* * *, * *, * \text { Indicate significance at } 1 \text { percent, } 5 \text { percent, and } 10 \text { percent levels respectively. The } \\
\text { parameter estimates are based on the following model: }\end{array}$} \\
\hline
\end{tabular}

Table (5) presents the results of multivariate pooled regression analysis for the second model used in this study. As can be seen from the table, there is a significant positive relationship between corporate governance and foreign direct investment.

\begin{tabular}{|c|c|c|c|c|}
\hline \multicolumn{5}{|c|}{$\begin{array}{l}\text { Table } 6 \\
\text { Results of Multivariate Regression Analysis }\end{array}$} \\
\hline Variables & Coefficients & t. Statistic & $\mathrm{p}$-value & \\
\hline NCG & 0.2053851 & $4.08 * * *$ & 0.000 & \\
\hline Cons & 0.1919954 & $5.80^{* * * *}$ & 0.000 & \\
\hline Adj R-squared & \multicolumn{4}{|l|}{$31.74 \%$} \\
\hline \multirow{2}{*}{\multicolumn{5}{|c|}{$\begin{array}{l}* * *, * * * \text { Indicate significance at } 1 \text { percent, } 5 \text { percent, and } 10 \text { percent levels respectively. The } \\
\text { parameter estimates are based on the following model: } \\
\quad=\quad \beta_{0+} \beta_{1} N C G_{t+\varepsilon}\end{array}$}} \\
\hline & $=$ & & & $t$ \\
\hline
\end{tabular}

\section{Conclusions and Recommendations}

\section{Conclusion}

This study intends to explore the relationship between the independent variables (factors) with corporate governance and dependent variables in order to find whether the factors (variables) taken under consideration in this study which are Earnings per Share (EPS), Liquidity (LIQ), Size (S), Return on Assets (ROA), Return on Equity (ROE), can determine foreign direct investment indicator through corporate governance, for a sample of Jordanian commercial banks. To reach our goal, we did the study in two steps. First, we studied the direct effect of our factors on corporate governance. Second, we studied the effect of corporate governance (fitted value) and foreign direct investment.

- Profitability: The study finds that there is a direct positive relationship between profitability -measured either by (EPS) or (ROA) - and corporate governance.

- Liquidity: The study finds a negative direct relationship between liquidity and corporate governance, as the liquidity of Jordanian commercial banks increases, it will result in a good corporate governance practices.

- Size: The study finds that there is a negative relationship between the size of the bank (measured by Log TA) and the corporate governance of the Jordanian commercial banks. 
- Return on Equity: The study explores a negative direct relationship between return on equity and corporate governance. This result is consistent with Brown and Caylor (2004).

- Corporate Governance: The study finds a positive direct relationship between corporate governance and foreign direct investment. When the bank has good corporate governance practices it will be attract foreign direct investment.

\section{Recommendations}

- Jordanian commercial banks should take into consideration, the main factors: EPS, ROA, liquidity, size and ROE that was found significant in determining corporate governance and foreign direct investment.

- The Jordanian companies have to focus on improving their corporate governance practices, which will lead to attract foreign direct investment by the following steps:

- Excessive efforts should be exerted by Jordanian bank in cooperation with Jordanian Securities Commission (JSC) and other regulatory bodies to adopt standard classification of items in the financial statements by assigning each element a uniform code to be used always in entering, processing data.

- Providing shareholders with periodic reports on changes affecting the shareholders in the company, and held regular meetings with members of the Board of Directors ensuring that their role should be done to share in the responsibility.

- Publication of manual rules of corporate governance and contributing to the public in order to benefit from the application of rules by the management and employees and the various activities of the company.

- Conduct further studies and taking into consideration other sectors and variables wasn't been taken by this study.

\section{References}

Adelopo, Ismail A. and Omoteso, Kamil and Obalola, Musa (2009). Impact of Corporate Governance on Foreign Direct Investment in Nigeria. Available : https://ssrn.com/abstract=1514982 or http://dx. doi.org/10.2139/ssrn.1514982

Ajay S. Ibi. (2006). Foreign Direct Investment in Sub-Saharan Africa: Origins, Targets, Impact and Potential. African Economic Research Consortium. Nairobi, Kenya, ISBN: 9966-944.

Alba, Joseph D.; Park, Donghyun; Wang, Peiming. (2010). Corporate Governance and Foreign Direct Investment. (c) Asian Development Bank. http://hdl.handle.net/11540/1954. License: CC BY 3.0 IGO.

Alba, Joseph D.; Park, Donghyun; Wang, Peiming. (2009). Corporate Governance and Merger and Acquisition (M\&a) FDI: firm-level Evidence from japanese FDI into thr US. Journal of multinational financial management 19:1-11

Alsubaie, A. (2012). The Influence of Foreign Direct Investment on Corporate-Governance Practices: a Conceptual Framework, International Conference on Arts, Economics and Literature (ICAEL'2012) December 14-15, 2012 Singapore.

Brown, S. \& Caylor, D. (2004). Corporate Governance and Firm Performance, European Financial Management, Vol. 2, No. 10, pp 151-170.

Chen, Shuping; Huang, Ying; Li, Ningzhong; Shevlin, Terry, 2019. "How does quasi-indexer ownership affect corporate tax planning?," Journal of Accounting and Economics, Elsevier, Vol. 67(2), pages 278-296.

Ching, K. W.; Tan, J.S. \& Chi Ching R. G. (2006) "Corporate Governance in East Asia, The Road Ahead". Prentice Hall Publication.

Ezekiel Oluwagbemiga Oyerogba. (2018). Corporate governance practices and foreign direct investment: the case of Nigerian listed companies, International Journal of Accounting and Finance, Vol. 8, Issue 4, pp. 312339.

Jensen, M. C. 1993. The modern industrial revolution, exit and the failure of internal control systems. Journal of Finance, 48: 831-880.Kolsi, M. C., \& Grassa, R. (2017). Did corporate governance mechanisms affect earnings management? Further evidence from GCC Islamic banks. International Journal of Islamic and Middle Eastern Finance and Management, 10(1), 2-23.

Madura, J (2015). International Financial Management, 12 ed, Cengage Learning, Florida Atlantic University.

Mersni, H., \& Ben Othman, H. (2016). The impact of corporate governance mechanisms on earnings management in Islamic banks in the Middle East region. Journal of Islamic Accounting and Business Research, 7(4), 318-348.

Peasnell, K. V., Pope, P. F., \& Young, S. (2005). Board Monitoring and Earnings Management: Do Outside Directors Influence Abnormal Accruals? Journal of Business Finance \& Accounting, 32, 1311-46. http://dx.doi.org/10.1111/j.0306-686X.2005.00630.x 
Praveen Das (2014). The Role of Corporate Governance In Foreign Investment. Journal Applied Financial Economics. Vol. 24, Issue 3 Pp 187-201

Ross, Steven, (1973). The economic theory of agency: The principal's problem. American Economic Review, 63(2): 134-139.

Rupesh Kumar, Gupta (2013), "Effects of Corporate Governance on Foreign Direct Investment”, International Journal of Management, MIT College of Management, Vol. 1, No.1, pp. 46-51

Shleifer, Andrei \& Vishny, Robert W., A (1997). Survey of Corporate Governance. Journal of Finance, Vol 52, No. 2.

Tunay, K. Batu \& Yüksel, Serhat (2017). The relationship between corporate governance and foreign ownership of the banks in developing countries, Contaduría y administración, Vol. 62, no. 5, 2017, pp. 1627-1642.

UNCTAD (2019). available at: http://www.unctad.org/templates/Page.asp?intItemID=3146\&la ng=1, last accessed on $29 / 09 / 2019$

World Bank (2019). Available at: https://www.worldbank.org/ last accessed on 23/11/2019 